\title{
Effect of using Jojoba and Moringa protein concentrate as a fat mimetic on physical and sensory properties of cupcake.
}

\author{
Makpoul KR*, Ibraheem AA, Amira MS \\ Food Science and Technology, Agricultural Industrialization Unite, Desert Research Center, Cairo, Egypt
}

\begin{abstract}
This research study was primarily conducted for the purpose to examine the Jojoba and Moringa protein concentrate as a fat mimetic on physical and sensory properties of cupcake. Fat replacers can be used to help decrease the amount of fats used in cooking; therefore, these health risks can be reduced. This study showed that Sensory quality was assessed by ten experienced panelists from Desert Research center, using attributes such as bread taste, flavor, firmness, softness, crumb and crust colors, appearance and overall acceptability. Principal components and cluster analyses confirmed two groupings of treatments with Jojoba and Moringa protein concentrate as a fat mimetic. It is concluded that treatments with $25 \%$ and $50 \%$ fat replacement were tastier and more acceptable. Finally, Jojoba and M. olifeira protein concentrate presented good functionality for utilization in food formulations.
\end{abstract}

Keywords: Jojoba, Moringa, Protein concentrate, Fat mimetic and cupcake.

\section{Introduction}

Now-a-days people are very particular about their relation between diet and health and more over they prefer food of low calorie which is healthy to the body. Usually for any occasion cakes are preferred first and which always been the children favourite food. Apart from the diet foods, cakes, burgers, pizzas, etc. are playing major role in the eatables. In return they are causing diseases such as constipation, tumours and heart attacks. In order to prevent the major health problems right food at right time must be taken. Proteins which paly major role in the diet. Essential proteins are not synthesized from our body they are consumed through taking vegetables, fruits, etc. whereas nonessential proteins are synthesized in body itself. Deficiency of proteins causes the serious problems such as malnutrition (marasmus and kwashiorkor) plant proteins are preferred first because they worth low and effective compared to animal protein [1].

On other hand fat contributes to flavor, or the combined perception of mouthfeel, taste, and aroma/odor. Fat additionally contributes to thickness, appearance, taste property, texture, and lubricity of foods and will increase the sensation of fullness throughout meals. Fat replacers are categorized into two types which are Fat substitutes and fat mimetis Fat substitutes are similar to fats which replaces triglycerides in food. Particular examples of fat substitutes are sucrose polyesters, which cannot be digested in small intestine and are passed directly into large intestine. Fats Mimetics can be carbohydrates or proteins and can replace fats in foods because of their textural organoleptic properties. Beside fats dietary fiber is believed to have positive effects on Human Nutrition and Human Health. And anyway, high intake of food which is rich in of dietary fiber is associated with lower risk of many diseases such as chronic bowel diseases, coronary heart diseases, and a various types of cancer [2].
Jojoba (Simmondsia chinensis (Link) Schneider) is an oil yielding desert shrub (family Simmondsiaceae) of arid and semi-arid areas [3]. Commercially Jojoba is grown for its oil which having lubricating properties. Besides being known for its lubrication, Jojoba has attracted interest towards, cosmetics, pharmaceuticals, animal feeding, and landscape as soil conservation [4]. Jojoba seeds have also been used in cleaning of aquatic system mainly for the removal of access ferric ions [5]. After oil extraction its defatted meal, represent a potential supplement for animal feeds. Once defatted, the major constituents of it are proteins $(31 \%)$ and carbohydrates (55\%) [6].

Jojoba industry faces the challenge of finding ways to improve productivity and quality of the products. There are number of different Jojoba accessions which are grown in Jojoba farms. This is mandatory to comparably evaluate them for its commercially important chemical properties [4].

Moringa oleifera (Moringaceae), which is fast growing tree and has fragile branches, tripinnaye leaves. They grow in semiarid and tropical regions. They are used in herbal medicine and pharmaceutical cosmetics too. They are given to infants and nursing mothers to fight malnutrition. The relative lack of anti-nutritional elements and also the high macromolecule, super-molecule Associate in nursing sulphur containing organic compound contents encourage the employment of Moringa seed as an animal feed. It's a wonderful supply of proteins for monogastric animals. The inhibitor action of some compounds gift within the plant, one amongst the foremost necessary physiological roles of food, will defend organisms against the hurtful effects of oxidization.

\section{Objectives of the study}

Thus, the aim of this study were to research the practicableness of victimization the Jojoba and Moringa super molecule 
Citation: Makpoul KR, Ibraheem AA, Amira MS. Effect of using Jojoba and Moringa protein concentrate as a fat mimetic on physical and sensory properties of cupcake. J Nutr Hum Health. 2017;1(1):17-23.

concentrate as a fat mimetic and to check its result on physical and sensory properties of cake. For this purpose, seven different formulations were examined which was the control cake (without protein concentrate) and cake with fat replacement of 25,50 and $75 \% \mathrm{w} / \mathrm{w}$.

\section{Materials and Methods}

The following procedure was adopted by the researcher for the purpose to reach at certain findings and conclusion.

\section{Preparation of protein concentrate}

The concentrates from pressed meal were prepared according to methods described [7]. A pressed cake (meal) was obtained from a press operation and extracted with hexane until the solvent was no longer colored. The defatted meal was spread out in trays to dry overnight at $20^{\circ} \mathrm{C}$. the defatted meal was subsequently ground with a hammer mill through 60 mesh screens. Protein concentrate were obtained by extracting the defatted meal with hexane solvent $(1: 20, \mathrm{w} / \mathrm{v})$ at $20^{\circ} \mathrm{C}$. SDI (spray-dried concentrate I) was obtained after washing the meal with methanol / acetone (3:1) and by rewashing SDI protein concentrate with a solution of methanol and IN HC1 (98:2) (SDII).

\section{Processing of cupcakes formulas}

All formulas of substituted wheat flour at different substitution levels by both protein concentrates were summarized in Table 1. The processing method of cupcake was taken typically according to AACC [8] in steps sequence as: The shortening was melted thoroughly; sugar and salt were added then mixed vigorously. The whole egg was mixed with vanilla and whipped until got puff and smooth like-cream texture. Additionally, substituted wheat flour (72\% extraction) with baking powder and skimmed milk powder then added gradually to whipped egg mixture. This mixture was mixed gently until got homogenous dough using Hand mixer (MK-H4-W, Panasonic Co). After getting appropriate texture the dough was poured into paper cups and backed at $180^{\circ} \mathrm{C} \pm 5^{\circ} \mathrm{C}$ for 30 to $35 \mathrm{~min}$. The baked cupcakes were cooled down at room temperature, and then packed into aluminum foil bags intervals for analysis. Six fat mixes were prepared from Jojoba protein with shortening and Moringa protein with shortening as shown in Table 2.

Table 1. Raw ingredients of processed cupcake.

\begin{tabular}{|c|c|}
\hline Ingredients & Weight $\mathbf{( g )}$ \\
\hline Soft wheat flour (72\% extraction) & 250 \\
\hline Sugar & 125 \\
\hline Salt & 3.5 \\
\hline Skimmed milk powder & 25 \\
\hline Shortening & 53.5 \\
\hline Fresh whole egg & 110 \\
\hline Baking powder & 12.5 \\
\hline Vanilla & 2 \\
\hline
\end{tabular}

\section{Proximate analysis}

Water, protein, fat, crude fiber, ash, contents of the raw materials and the cupcakes were determined according to the methods of AOAC [9]. Total carbohydrates (TC) were calculated by difference.

2-4 Amino acids: Amino acids were determined using a BECKMAN 6300 amino acid analyzer according to the method of Spackman [10]. Hydrolysis of samples was performed in the presence of $6 \mathrm{M} \mathrm{HCl}$, trifluoroacetic acid (TFA, 2:1, v/v) and $5 \%$ thioglycolic acid, for $24 \mathrm{~h}$ at $100^{\circ} \mathrm{C}$ prior to amino acid analysis.

2-5 Physical characteristics: The normal weight of baked cupcakes was individually determined within $1 \mathrm{~h}$ after baking. Also, volume in different substituted cupcakes was determined by method according to AACC [11] and specific volume was calculated for these formulas [Volume $\left(\mathrm{cm}^{3}\right) /$ Weight $(\mathrm{g})$ ].

2-6 Sensory evaluation: Cupcakes were evaluated for its sensory characteristics, i.e., taste, odor, appearance, crust color, crumb color and crumb texture. The evaluation was carried out by ten experienced panelists from Desert Research center, according to the method of Larmond [12]. A 9-point scale was used for the sensory evaluation: (1) very bad, (2) bad, (3) poor, (4) relatively poor, (5) intermediate, (6) good, (7) very good, (8) excellent, and (9) very excellent.

\section{Results and Discussion}

\section{Proximate composition and yield of protein concentration}

The proximate composition of Jojoba and Moringa defatted seed meal is presented in Figure 1. Protein was the major macromolecule in Jojoba defatted seed meal (35.8\%) after carbohydrates $(43.2 \%)$. Higher protein content values were reported for Moringa defatted seed meal (58.4\%). Jojoba meal reported higher content of fiber, moisture and ash $(13.1 \%, 3.9 \%$ and $3.7 \%$ respectively) than Moringa meal (4.9\%, 2.7\% and $2.3 \%$ respectively). Protein content was significantly $(\mathrm{p}<0.05)$ higher in $M$. oleifera meal compared to Jojoba meal. Defatted seed meal was found to have fat content about ( 0.3 and $0.1 \%)$ for Jojoba and Moringa respectively.

The concentrate pressed meals were reduce weight from $50 \%$ to $55 \%$ while removing simmondsin content in Jojoba and pressed meals and reduced content of polyphenol in all concentrate of Jojoba and Moringa. The functional properties were investigated most thoroughly with the SDII concentrate because this concentrate had the lowest concentration of simmondsin, a toxic compound in Jojoba, and polyphenolic compounds [7]. The concentration of simmondsin must be reduced before Jojoba meal or protein concentrates can be used in food or feed products. Table 3 shows the protein yield of pressed meal

Table 2. Formula of the cupcakes.

\begin{tabular}{|c|c|c|c|c|c|c|c|}
\hline \multicolumn{4}{|c|}{7} & \multicolumn{4}{|c|}{ Moringa } \\
\hline Sample & Shortening & Jojoba protein & Fat (\%) & Sample & Shortening & Moringa protein & Fat (\%) \\
\hline Control & 53.5 & - & 100 & Control & 53.5 & - & 100 \\
\hline JP 25 & 40 & 13.5 & 75 & MP 25 & 40 & 13.5 & 75 \\
\hline JP 50 & 26.75 & 26.75 & 50 & MP 50 & 26.75 & 26.75 & 50 \\
\hline JP 75 & 13.5 & 40 & 25 & MP 75 & 13.5 & 40 & 25 \\
\hline
\end{tabular}


concentrate of Jojoba and Moringa SDI. Water extractable protein obtained after washing the meal with methanol/acetone solution, SDII. SDI protein concentrates after washing with a methanol/ $\mathrm{HCl}$ solution

\section{Amino acid composition}

The amino acid composition of Jojoba and Moringa defatted seed meal is presented in Table 4. Regarding essential amino acids content, both Jojoba and Moringa meal were found to be rich in leucine (6.24 and $7.43 \%$, respectively) and valine (4.32 and $7.24 \%$, respectively). Jojoba defatted seed meal showed higher isoleucine, lysine, Tyrosine and Serine contents than

Table 3. Protein yield of Jojoba and Moringa defatted seed meal.

\begin{tabular}{|c|c|c|c|}
\hline Sample & $\begin{array}{c}\text { Protein } \\
\text { concentrate \% }\end{array}$ & Meal concentrate $\mathbf{( g / g )}$ & Protein yield $(\mathbf{g} / \mathbf{g})$ \\
\hline Jojoba SDI & $34^{\mathrm{d}}$ & $0.47^{\mathrm{b}}$ & $0.159^{\mathrm{d}}$ \\
\hline Jojoba SDII & $36^{\mathrm{c}}$ & $0.45^{\mathrm{d}}$ & $0.162^{\mathrm{c}}$ \\
\hline Moringa SDI & $55^{\mathrm{b}}$ & $0.50^{\mathrm{a}}$ & $0.275^{\mathrm{a}}$ \\
\hline Moringa SDII & $58^{\mathrm{a}}$ & $0.46^{\mathrm{c}}$ & $0.267^{\mathrm{b}}$ \\
\hline
\end{tabular}

Table 4. Amino acids composition of defatted seed meal Jojoba and M. oleifera ( $\mathrm{g} / 100 \mathrm{~g}$ protein).

\begin{tabular}{|c|c|c|}
\hline Amino acids & Jojoba & M. oleifera \\
\hline Leucine & 6.24 & 7.43 \\
\hline Lysine & 4.68 & 2.32 \\
\hline Threonine & 1.43 & 4.15 \\
\hline Tryptophan & 3.69 & - \\
\hline Isoleucine & 4.73 & 4.38 \\
\hline Valine & 4.32 & 7.24 \\
\hline Methionine & 1.84 & 1.68 \\
\hline Tyrosine & 3.68 & 2.38 \\
\hline Cysteine & 1.47 & 1.21 \\
\hline Phenylalanine & 5.34 & 5.42 \\
\hline Total essential amino acids & 37.42 & 36.21 \\
\hline Serine & 4.93 & 3.72 \\
\hline Proline & 5.34 & 6.43 \\
\hline Glycine & 8.32 & 12.61 \\
\hline Alanine & 4.67 & 6.94 \\
\hline Arginine & 5.74 & 5.37 \\
\hline Histidine & 2.71 & 2.94 \\
\hline Glutamic & 16.48 & 22.37 \\
\hline Aspartic & 12.73 & 8.63 \\
\hline Total amino acids & 60.92 & 69.01 \\
\hline & 98.34 & 105.22 \\
\hline
\end{tabular}

- Jojoba
Moringa defatted seed meal. It was also Moringa meal was poor in Tryptophan. The major nonessential amino acids were observed to be glutamic acid (16.48\% and $22.37 \%)$ and glycine (8.32\% and 12.61\%), respectively for Jojoba and Moringa defatted seed meal leaf. The quality of proteins as source of amino acids can usually be adequately assessed by comparison with the FAO/OMS [13-18] recommended qualified an ideal protein as one in which $36 \%$ the total residues of essential amino acids. Compared to the defatted seed meal of Jojoba and Moringa reported higher total essential amino acids content, and both meal had higher total essential amino acids than the FAO/OMS [18-24] reference pattern. These results showed that Jojoba and Moringa defatted seed meal could be used as a source of proteins, which contain high amount of proteins.

\section{Chemical analysis of cupcakes}

Tables 5 and 6 presents the values of the chemical analysis of cupcakes. The moisture content found increased in the cupcake with Jojoba and Moringa protein concentrate with a significant difference at $\mathrm{p}<0.05$. Therefore, that absorption of water by the protein concentrates generally increased with temperature increased, the results revealed that the water absorption increased with the increasing levels of protein concentrate [2529]. The determination of moisture is one of the most important measurements and is used in food analysis because it is related to its stability, quality and composition, and can affect the storage, packaging and processing.

The amount of protein found in the samples enriched with $75 \%$ Jojoba and Moringa protein had higher protein content (32 g) and the samples containing 50\% Jojoba and Moringa protein had $(8 \%)$ increasing in protein content $(27 \mathrm{~g})$. Also, samples with $25 \%$ protein concentrate of Jojoba and Moringa in the formulation of cupcakes that led to significantly increase in protein content (4\%) (23 g). The values obtained in the analysis of lipids were $2.8 \%$ and $2.3 \%$ for the samples with $75 \%$ of Jojoba and Moringa protein concentrate respectively and $(5.3 \%, 4.5 \%$ respectively) for samples with $50 \%$ Jojoba protein and Moringa protein with significant difference at $\mathrm{p}<0.05$ when compared with those of control sample (10.2\%). Thus it can be indicate that the products have relatively low lipid.

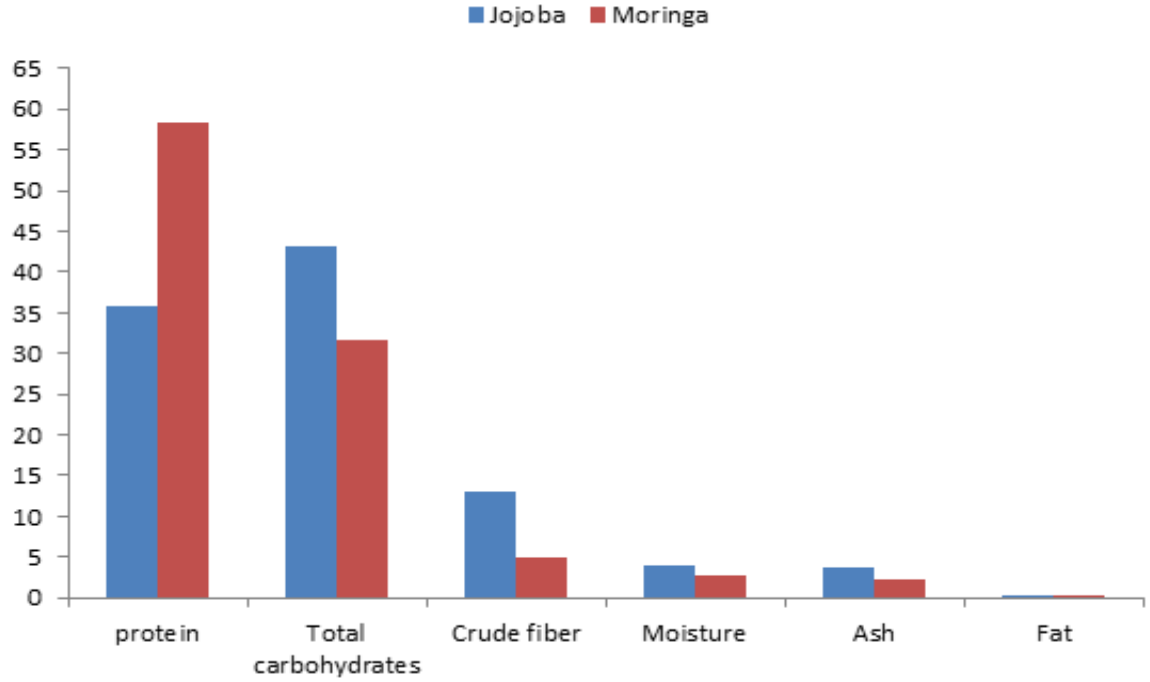

Figure 1. Proximate composition (g/100 g) of Jojoba and Moringa defatted seed meal. 
Citation: Makpoul KR, Ibraheem AA, Amira MS. Effect of using Jojoba and Moringa protein concentrate as a fat mimetic on physical and sensory properties of cupcake. J Nutr Hum Health. 2017;1(1):17-23.

Table 5. Proximate composition ( $\mathrm{g} / 100 \mathrm{~g}$ ) of cupcake with Jojoba defatted seed meal.

\begin{tabular}{|c|c|c|c|c|c|c|}
\hline Sample & Protein & Total carbohydrates & Crude fiber & Moisture & Ash & Fat \\
\hline Control & $19.6^{d}$ & $52.5^{\mathrm{a}}$ & $1.3^{\mathrm{a}}$ & $15.4^{\mathrm{d}}$ & $1.07^{\mathrm{a}}$ & $10.2^{\mathrm{a}}$ \\
\hline Jojoba 25 & $23.4^{c}$ & $49.8^{b}$ & $1.3^{\mathrm{a}}$ & $16.3^{c}$ & $1.06^{\mathrm{a}}$ & $8.1^{\mathrm{b}}$ \\
\hline Jojoba 50 & $27.6^{\mathrm{b}}$ & $46.1^{c}$ & $1.3^{\mathrm{a}}$ & $18.7^{\mathrm{b}}$ & $1.09^{a}$ & $5.3^{c}$ \\
\hline Jojoba 75 & $32.1^{\mathrm{a}}$ & $40.5^{d}$ & $1.3^{\mathrm{a}}$ & $22.1^{\mathrm{a}}$ & $1.14^{\mathrm{a}}$ & $2.8^{d}$ \\
\hline
\end{tabular}

Data are presented as means $\pm S D(n=3)$ and Means within a column with different letters are significantly different at $(P \leq 0.05)$

\section{Physical characteristics}

The effect of Jojoba and Moringa protein concentrate on cupcake physical properties was considered, data were illustrated in Table 7. Increasing of Jojoba and Moringa protein substitution level increased weight property. Accordingly, increasing either Jojoba or Moringa protein concentrate levels could bind more water led to increasing weight. Volume of cupcakes is affected by various factors such as quality of flour, type of ingredients and processing conditions. As for volume and specific volume characteristics, significant differences $(p<0.05)$ were exhibited between all cupcakes [30-33]. The mean values for the volume of cupcakes indicated that the maximum value for volume was observed in control sample $\left(107.35 \mathrm{~cm}^{3}\right)$ followed by Jojoba 25 and Moringa 25 while the minimum value was observed in Jojoba 75 and Moringa 75. Increasing protein concentrate levels could lead to decrease the volume and specific volume thinks to influence on gluten net with low strength and gas retention.

According to Table 7, the sample containing $75 \%$ concentrate protein from Jojoba and Moringa had the lowest specific volume. It should be noted that not only proteins have the ability to be a suitable fat replacer, but also they have the ability to strengthen the cell walls and do not allow the walls to be torn. The important point is that if we use excessive amount of additives in the formulation, it may hamper the air bubbles expansion during baking process due to the excessive increase in the strength of the their wall and therefore, not only there is no increase in volume of the final product texture, but also the texture is hard and compressed. In this study, the high levels of concentrate protein caused the same problem in low-fat cupcake.

\section{Sensory characteristics}

Figure 2 shows the interaction of concentrate protein of Jojoba and Moringa on the score given in sensory evaluation cupcakes produced samples. According to Figure 2, the highest smell, taste score was given to the sample containing 25 and $50 \%$ concentrate protein of Jojoba and Moringa. Also, it is more likely that reduction of sweet taste in the samples containing $75 \%$ concentrate protein, which was reported by the panelists, is affected by the undesirable taste. Since samples containing $75 \%$ concentrate protein had a hard, sticky and unswallow able texture comparing to the sample containing $25 \%$ and $50 \%$ of concentrate protein, an impaired release of flavor producers happens. Therefore, if an appropriate amount of Jojoba and Moringa concentrate protein are used during the process of replacing oil, besides having a desirable texture, flavor producers.

The results showed that form of the samples containing $25 \%$ concentrate protein were more superior to the other samples. The panelists expressed that the unexpectedly crumb and crust color of the sample containing $75 \%$ concentrate protein, was the main reason for the low rating. It should be noted, based on the panelists" decision, the sample containing $25 \%$ and $50 \%$ protein concentrate of Jojoba and Moringa was better than the sample containing $75 \%$ of it, in terms of upper surface characteristics. Because according to some sensory panelists, there can be seen tiny black particles on the surface of the sample containing $75 \%$ of protein concentrate that consequently, the desirability of the final product was reduced. On the other hand, the sample containing 25\% Jojoba and Moringa protein was more superior to the control sample due to its brighter colored surface. On the other hand, a darker appearance is seen in the samples containing high levels of concentrate protein, which was unexpectable and considered as a burnt cupcake by the panelists. Also, there was a report on abnormal surface (sticky surface) that was apparently due to too much water absorption of the cupcake samples containing high level of protein used in the formulation of lowfat cupcake.

Table 6. Proximate composition ( $\mathrm{g} / 100 \mathrm{~g}$ ) of cupcake with M. oleifera defatted seed meal.

\begin{tabular}{|c|c|c|c|c|c|c|}
\hline Sample & Protein & Total carbohydrates & Crude fiber & Moisture & Ash & Fat \\
\hline Control & $19.6^{d}$ & $52.5^{\mathrm{a}}$ & $1.3^{\mathrm{a}}$ & $15.4^{\mathrm{d}}$ & $1.07^{\mathrm{a}}$ & $10.2^{\mathrm{a}}$ \\
\hline Moringa 25 & $23.6^{\mathrm{c}}$ & $49.7^{b}$ & $1.3^{\mathrm{a}}$ & $16.9^{c}$ & $1.08^{\mathrm{a}}$ & $7.5^{\mathrm{b}}$ \\
\hline Moringa 50 & $27.8^{\mathrm{b}}$ & $46.2^{c}$ & $1.3^{\mathrm{a}}$ & $19.1^{\mathrm{b}}$ & $1.14^{\mathrm{a}}$ & $4.5^{\mathrm{c}}$ \\
\hline Moringa 75 & $30.2^{\mathrm{a}}$ & $42.4^{\mathrm{d}}$ & $1.3^{\mathrm{a}}$ & $22.7^{\mathrm{a}}$ & $1.17^{\mathrm{a}}$ & $2.3^{\mathrm{d}}$ \\
\hline
\end{tabular}

Table 7. Physical characteristics of cupcakes with Jojoba and Moringa protein concentrate.

\begin{tabular}{|c|c|c|c|}
\hline Sample & Weight (g) & Volume $\left(\mathrm{cm}^{3}\right)$ & Specific volume $\left(\mathrm{cm}^{3} / \mathrm{g}\right)$ \\
\hline Control & $41.18^{e}$ & $107.35^{\mathrm{a}}$ & $2.61^{\mathrm{a}}$ \\
\hline Jojoba 25 & $41.94^{\mathrm{e}}$ & $107.04^{b}$ & $2.55^{\mathrm{b}}$ \\
\hline Jojoba 50 & $43.47^{d}$ & $105.73^{c}$ & $2.43^{c}$ \\
\hline Jojoba 75 & $46.72^{b}$ & $102.92^{\mathrm{d}}$ & $2.20^{\mathrm{e}}$ \\
\hline Moringa 25 & $41.81^{\mathrm{e}}$ & $107.06^{b}$ & $2.56^{\mathrm{b}}$ \\
\hline Moringa 50 & $44.37^{c}$ & $105.68^{c}$ & $2.38^{d}$ \\
\hline Moringa 75 & $49.14^{\mathrm{a}}$ & $102.91^{\mathrm{d}}$ & $2.09^{f}$ \\
\hline
\end{tabular}




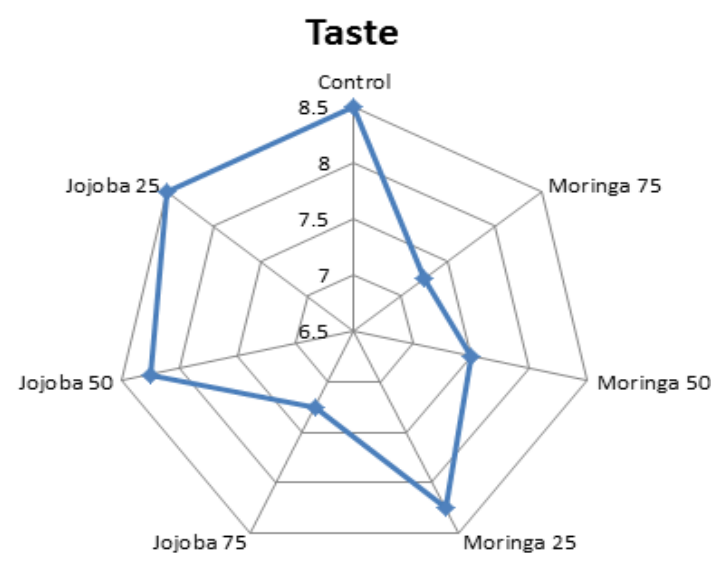

firmness

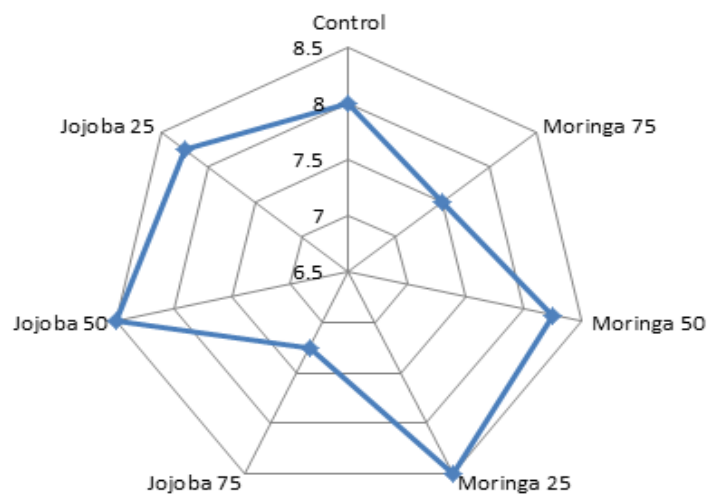

softness
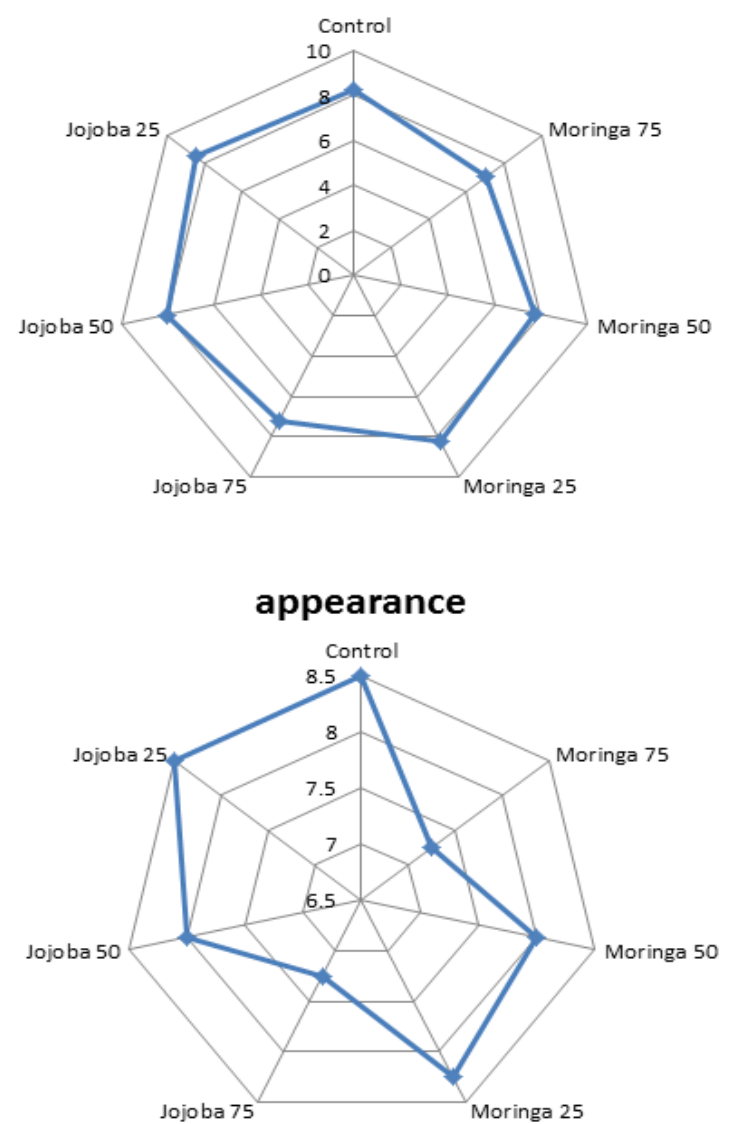

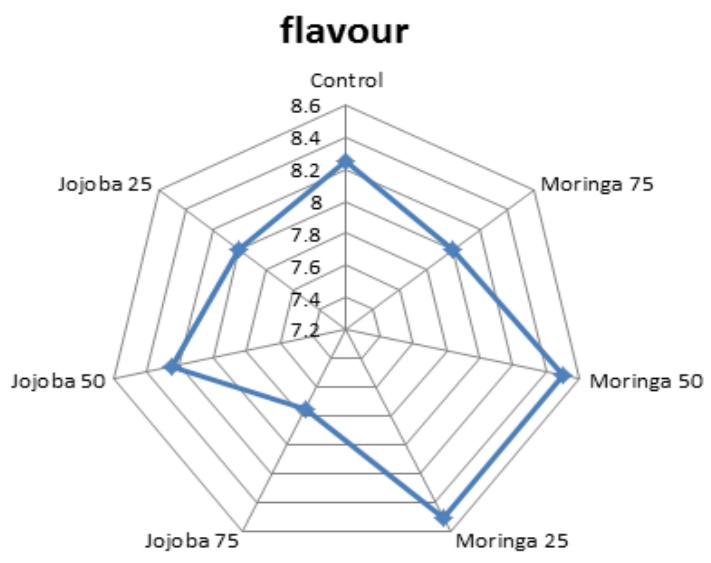

crumb color

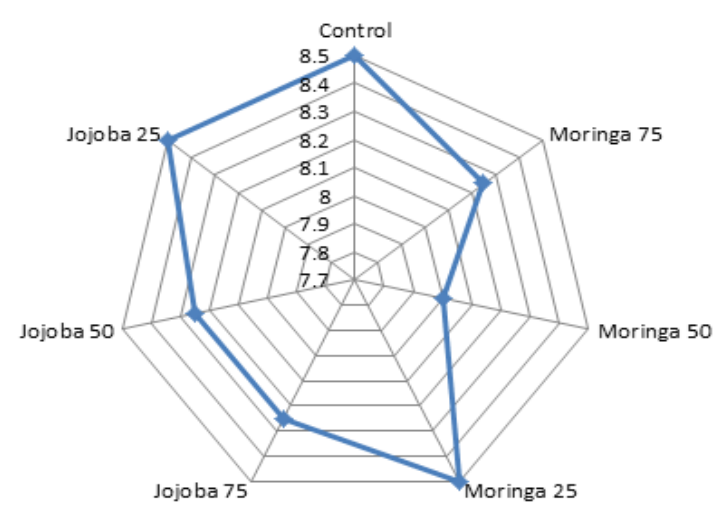

crust color

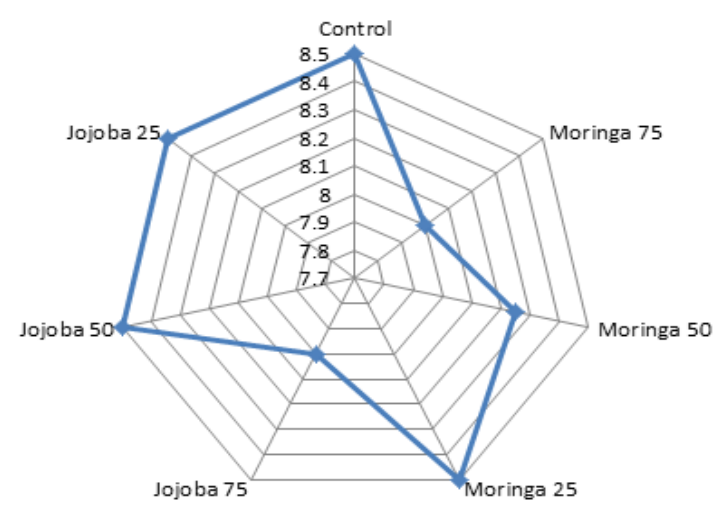

General acceptance

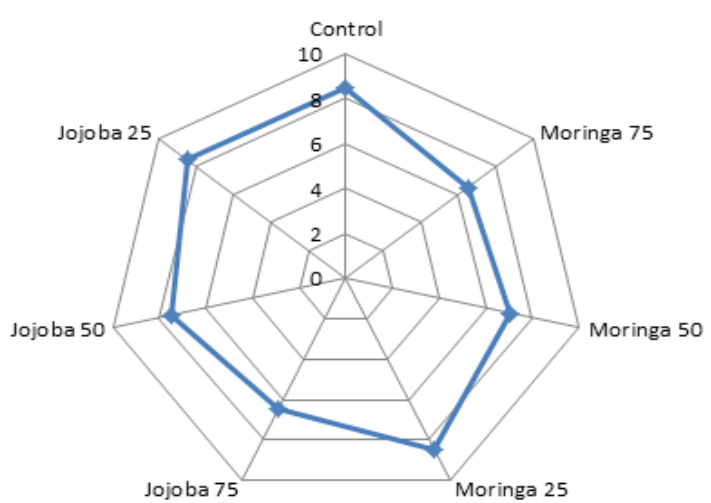

Figure 2. Acceptance and purchase intent of cupcakes. 
Citation: Makpoul KR, Ibraheem AA, Amira MS. Effect of using Jojoba and Moringa protein concentrate as a fat mimetic on physical and sensory properties of cupcake. J Nutr Hum Health. 2017;1(1):17-23.

According to the results of the evaluation of the texture of the low-fat cupcake samples, the sample containing $25 \%$ and $50 \%$ Jojoba and Moringa concentrate protein were given the high score on their texture qualitative properties, because this sample had the lowest amount of texture hardness than other samples. It was predicted that the sample containing $75 \%$ protein of Jojoba and Moringa receive the lowest scores regarding their softness and hardness.

According to results, the high overall acceptability was given to the sample containing 25\% and 50\% Jojoba and Moringa protein concentrate. Thus, since these two samples had the highest score in many parameters, it was expected that compared with other produced samples, their overall acceptability scores be at the highest level and the panelists introduced these two samples, as the samples of low-fat cupcake with high acceptable characteristics from the perspective of the consumer.

\section{Conclusion}

The results showed that with the increase of protein concentrate of Jojoba and Moringa contents, the general acceptance of the cupcake final products, we introduced the sample containing $25 \%$ protein concentrate of Jojoba and Moringa as the best sample. Then, the second level was acceptance in the study was content $50 \%$ of protein concentrates of Jojoba and Moringa. Based on the positive results of this study, the possibility to produce low-fat cupcakes with protein concentrate of Jojoba and Moringa with desired quantitative and qualitative properties is confirmed.

\section{References}

1. Sandrou DK, Arvanitoyannis IS. Low-fat/calorie foods: Current state and perspective. Crit Rev Food Sci Nutr. 2000;40:427-47.

2. Sampaio GR, Cláudia CMN, Castellucci MN, et al. Effect of fat replacers on the nutritive value and acceptability of beef frankfurters. J Food Compost Anal. 2004;17:469-74.

3. Kumar S, Singh N, Mangal M. Biochemical changes during shoot differentiation in callus cultures of Simmondsia chinensis (Link). Schneider Plant Biol. 2009;36(1/2):11-6.

4. Swati A, Khushboo C, Suphiya K, et al. Biochemical characterization of defatted meal of different accessions of Simmondsia chinensis (Link) C. K. schneid (Jojoba). Int J Sci Res Agric Sci. 2016;2(2):034-8.

5. Al-Anber MA, Al-Anber ZA, Al-Momani I, et al. The performance of defatted jojoba seeds for the removal of toxic high concentration of the aqueous ferric ion. Desalin Water Treat. 2014;52(1-3):293-304.

6. Kolodziejczyk PP, Lu W, Ayerza R, et al. Capillary electrophoresis: Novel tool for simmondsins analysis and its applications to jojoba breeding. Ind Crops Prod. 2007;12(3):193-202.

7. Wiseman MO, Price RL. Characterization of protein concentration of Jojoba (Simmondsis chinensis) meal. Cereal Chem.1987;64:91-3.
8. AACC (Approved methods of the American Association of Cereal Chemists) St Pauls, MN (USA). American Association of Cereal Chemists, 2000.

9. AOAC (Association of Official Analytical Chemist) Official Methods of Analysis. 18th edition. Washington DC, 2007.

10. Spackman DM, Stein WH, Moore S. Automatic recording apparatus for use in the chromatography of aminoacids. Anal Chem.1958;30:1190-206.

11. AACC (Approved Methods of the American Association of Cereal Chemists) 2002. American Association of Cereal Chemists, St. Paul, MN, USA, 2002.

12. Larmond E. Laboratory methods for sensory evaluation of food. 1997. Canada Agric Dept. Publ no. 1637.

13. FAO/OMS. Protein quality evaluation. Rome: In Food and Agricultural Organization of the United Nations, 1991.

14. Chronakis IS. Structural-functional and water-holding studies of biopolymers in low fat content spread. Food sci technol. 1997;30:36-44.

15. Cooper DA, Webb DR, Peters JC. Evaluation of the potential for Olestra to affect the availability of dietary phytochemicals. J Nutr.1997;127:1699S-1709S.

16. Ferreira PMP, Farias DF, Oliveira JTA, et al. Moringa oleifera: Compounds and nutritional potential.2008.

17. Hafez AA. Physico-chemical and sensory properties of cakes supplemented with different concentration of Marjoram. Austr J Basic Appl Sci. 2012;6:463-70.

18. Hsu SY, Sun LY. Comparisons on 10 non-meat protein fat substitutes for low-fat Kung-wans. J Food Eng. 2005;69.

19. Jonson BR. Whey protein concentrates in low-fat applications, published by U.S. dairy export council. 2002.

20. Khalafalla M, Abdellatef E. Active principle from Moringa oleifera lam leaves effective against two leukemias and a hepatocarcinoma. Afr J Biotechnol. 2010;9:8467-71.

21. Martin AMM, Emilienne CN, Christian BB, et al. A comparison on the nutritional quality of proteins from Moringa oleifera leaves and seeds. Cogent Food Agric. 2016;2:1213618.

22. Matsakidou A, Blekas G, Paraskevopoulou A, et al. Aroma and physical characteristics of cakes prepared by replacing margarine with extra virgin olive oil. LWT-Food Sci Technol. 2010;43:949-57.

23. Mohammad TG, Mahsa M, Aida R, et al. Investigation of physicochemical, nutritional, textural, and sensory properties of Iranian Yazdi cupcake enriched with Spirulina (Arthrospira platensis). International Conference on Latest Trends in Food, Biological and Ecological Sciences (ICLTFBE'15). 2015.

24. Muhammad SA, Masood SB, Muhammad TS, et al. Peanut protein isolates improve the nutritional quality of muffins that can be handy tool to cure protein energy malnutrition 
in developing economies. $\mathrm{J}$ Food Agric Environ. 2014;12(3\&4):51-5.

25. Oduro I, Ellis WO, Owusu D. Nutritional potential of two leafy vegetables: Moringa oleifera and Ipomoea batatas leaves. Sci res essay. 2008;3:57-60.

26. Okuda T, Baes AU, Nishijima W, et al. Isolation and characterization of coagulant extracted from moringa oleifera seed by salt solution. Water Res. 2001;35:405-10.

27. Peters JC, Lawson KD. Assessment of the nutritional effects of olestra, a non-absorbed fat replacement: Introduction and overview. J Nutr. 1997;127:1539S-46S.

28. Romanchik-Cerpovicz JE, Tilmon RW, Baldree KA. Moisture retention and consumer acceptability of chocolate bar cookies prepared with okra gum as a fat ingredient substitute. J Am Diet Associ. 2007;102(9):1301-03.

29. Romeih EA, Michaelidou A, Bilhaderis CG, et al. low- fat white- brined cheese made from bovine milk and two commercial fat mimetics: Chemical, physical and sensory attributes. Int Dairy J. 2002;12:525-40.

30. Sidhu JS, Al-Hooti SN, Al-Saqer JM, et al. Studies on the development of pan bread using raw wheat germ. J Food Quality. 2001;24:235-47.

31. Sipahioglu O, Alvarez VB, Solano-Lopez C. Structure, physico-chemical and sensory properties of feta cheese made with tapioca starch and lecithin as fat mimetics. Int Dairy J. 1999;9:783-9.

32. Specter SE, Setser CS. Sensory and physical properties of a reduced-calorie frozen dessert system made with milk fat and sucrose substitutes. J Dairy Sci. 1994;77:708-17.

33. Zalazar CA. Effect of moisture level and fat replacer on physicochemical, rheological and sensory properties of low fat soft cheeses. Int Dairy J. 2002;12:45-50.

\section{*Correspondence to:}

Makpoul KR

Department of Food Science and Technology

Agricultural Industrialization Unite

Desert Research Center, Cairo

Egypt

Tel: 002/01006266832

E-mail: khaledmakpoul@hotmail.com 